\title{
SNAKE AND STAFF SYMBOLISM AND HEALING
}

\begin{abstract}
Since time immemorial the snake has been venerated as an enigmatic creature with supernatural powers. As a snake and staff symbol it is also traditionally associated with the healing arts, either as the single-snake attribute of Asclepius, or as the doublesnake attribute of Hermes. In this article the mythological basis for this symbol is reviewed. The Asclepian emblem has been associated with health care since the $5^{\text {th }}$ century BC when Asclepius became accepted by the Greeks as the god of healing. Whether he was also an historical figure as healer in earlier ages is less certain. The origin of the double-snake emblem is shrouded in the mists of antiquity. In classical times it became the herald's wand (caduceus) of Hermes, messenger of the gods who guided departed souls to the Underworld, and was seen as the protector of travellers, shepherds and merchants. In the latter capacity Hermes also conveyed a negative connotation as protector of thieves. During the Middle Ages the caduceus entwined with the double-snake became a symbol of the healing sciences (pharmacy and alchemy in particular) and today, although mythologically incorrect, it is in common usage in the health care field.
\end{abstract}

\section{INTRODUCTION}

Since time immemorial the snake, probably more than any other animal, has been associated with religion and magical powers. And in conjunction with a staff it has also traditionally become a symbol of healing. In this article the origin of these symbols is traced with particular reference to their significance in the field of health care.

\section{THE SNAKE IN ANTIQUITY}

\subsection{Role in culture and mythology}

From the earliest records of civilisation it is clear that the snake played a significant cultural role as an enigmatic creature with supernatural powers, alternatively seen (even in the same community) as benevolent creator and protector of wisdom and eternal life, or perpetrator of evil and agent of death (Lurker 1989:370; Hendel 1995:1405). Serpents are mythologically associated with the origin of the world and creation, with veneration of ancestors, bestowal of wisdom and power and as symbol of mother earth and eternity. In Judaeo-Christian tradition 
(Allen 2000:203-225) it was the snake which ended life in Paradise by seducing Eve to eat from the tree of knowledge of good and evil. In ancient Greek mythology there were two classes of serpents - agathodaemon (beneficent), and kakodaemon (demonic) (Bunn 1967:615, 617). Cretan, Mycenean and Palestinian excavations produced numerous snake goddesses (Lurker 1989:370-374; Hendel 1995:1407; Bunn 1967: 616-7). In ancient Egypt the serpent was believed to be the first offspring of primeval earth, identified with the gods Seth and Apophis, and in constant warfare against the sun-god, Ra (Lurker 1989:370). The Uraeus snake symbol worn on the forehead became the Pharaoh's sign of sovereignty (Hendel 1995:1406; Bunn 1967:616). In many Northern European Celtic sagas and also elsewhere, snakes represented the Underworld or the earth goddess (often associated with fertility and long life), and in African folklore snakes are associated with spirits of the ancestors to this day (Lurker 1989:370-1). In the ancient Gilgamesh Epic the snake steals the secret of eternal youth from the human hero — and it is probable that the snake's ability to shed its skin gave origin to the belief that serpents were capable of eternal life (Lurker 1989: 370; Allen 2000:206-8; Bunn 1967:617). In India and the Far East, too, snakes were considered to exercise supernatural powers over humans (Lurker 1989:372-3). Snakes were often associated with the transfer of wisdom, and as late as Graeco-Roman times domestic snakes were kept as pets to bring good fortune to the household (Lurker 1989:370).

\subsection{Role in health care}

In early Egyptian civilisation there is already evidence of a supposed relationship between snakes and healing. In a hymn to the goddess Mertseger, a workman on the Necropolis of Thebes relates how the goddess came to him in the form of a snake to heal his illness (Bunn 1967:617). In Hammurabi's Law Code (c. 1700 BC) the god Ninazu is identified as the patron of healing, and his son, Ningishzida, is depicted with a serpent and staff symbol (Bunn 1967:618). In the Bible (Numbers 21:4-9) Moses erected a copper snake to assist in delivering the Israelites from a plague of fiery serpents in the desert. However, it was made clear to the Israelites that deliverance came from Yahweh and not from the symbol - and when the snake was later worshipped in the time of Hezekiah, it was destroyed (Allen 2000:203-225). The super- 
natural powers attributed to snakes by the ancient Hebrews, and the healing power of serpents in particular, are well summarised by Allan (2000:203-225) and Wassermann (1997:30-34).

The Gnostic religious sect (250 BC-AD 400) popularised the serpent god, Chnoubis, as a god of healing (Bunn 1967:618) but it is the Greek hero-god, Asclepius (Asklepios in Greek, Aesculapius in Latin) with his snake and staff attribute who is today best remembered as antiquity's health divinity (Schouten 1967:7-9).

\section{THE SNAKE AND STAFF EMBLEM}

Although a staff or rod was probably in common use in olden times as an aid in walking and as a weapon, it was also used by rulers in Egypt and Mesopotamia as a scepter or symbol of absolute power. The vegetable nature of the staff symbolised the indestructible vitality of the earth as represented in its vegetation (Schouten 1967:118; Allen 2000:203-4). Imhotep, grand vizier of King Djoser (2600 BC) who was also deified as a healer, was always depicted holding a stout staff. In many old Egyptian representations deities are shown holding erect serpents as staffs (Bunn 1967:616, 619). In Exodus 7:8-12 when Aaron cast his rod before the Pharaoh as a gesture of power, it turned into a snake. The magicians at court could do the same, but their snakes were then devoured by Aaron's. Fan (1992:273-4) reports that the snake and staff as emblem of healing has been known in China since $1700 \mathrm{BC}$. He hypothesises that it originated as a sex symbol - the erect penis (or snake) being seen as the origin of fertility and new life.

There are two basic varieties of the snake and staff symbol: the emblem associated with Asclepius (a single snake entwined around a staff), and that associated with Hermes (two snakes encircling a herald's wand, caduceus in Latin and kêrukeion in Greek).

\subsection{Emblem of Asclepius}

The classical representation is that of Asclepius leaning on a heavy staff (rhabdos) around which a single snake is coiled. Although he became well known in Greece as god of healing only towards the end of the $5^{\text {th }}$ century BC, Homer ( $8^{\text {th }}$ century BC) already mentions one Asclepius as a renowned healer who transmitted his skills to his two sons, 
Snake and staff symbolism and healing

Podaleiros and Machaon. Jayne (1925:248-9), however, is of the opinion that the information about his sons was added to the main text at a much later date. Machaon received the gift of surgery, while Podaleiros received the knowledge to diagnose and cure hidden and desperate illnesses. A third son, Telesphorus, always depicted as child, was commonly shown in art (Jayne 1925:248-9; Rose 1979:1041).

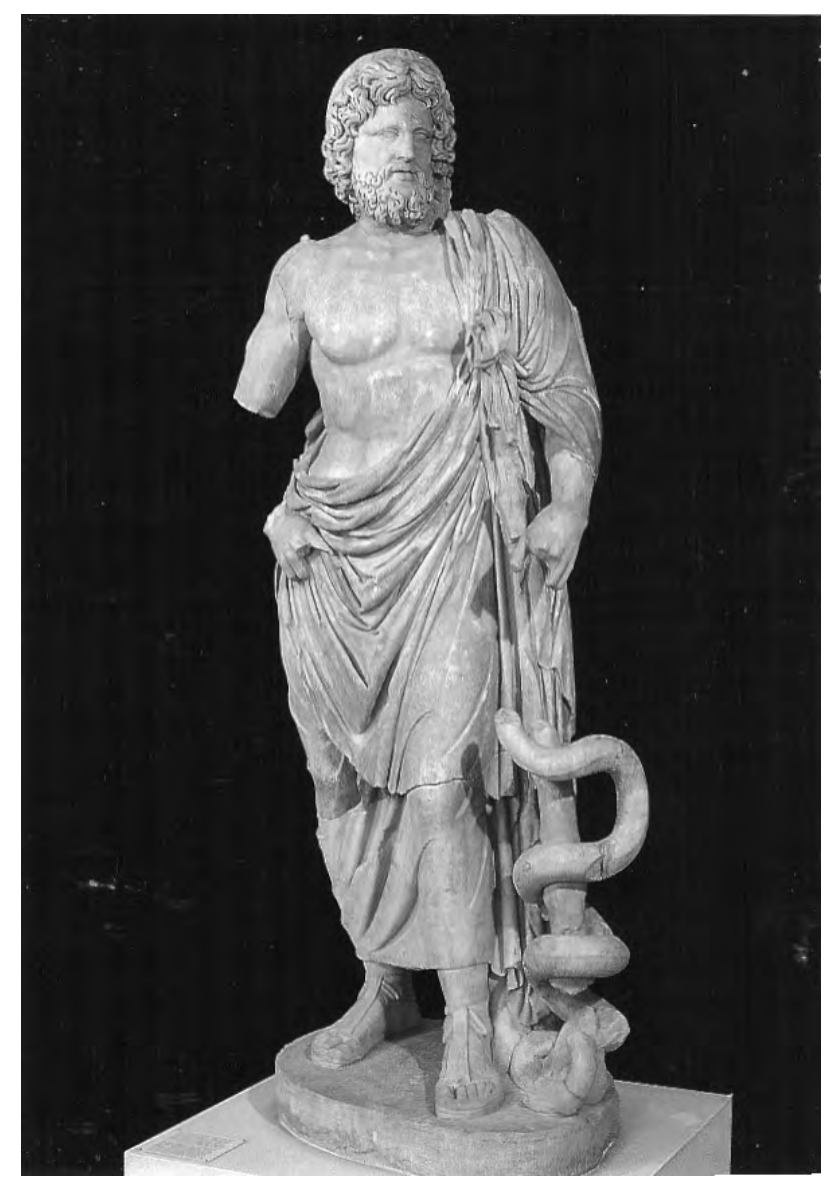

Figure 28: Asclepius with staff and single snake.

Epidaurus Museum. 
Writing in $475 \mathrm{BC}$, Pindar describes Asclepius as a hero, the son of the god Apollo and a married mortal woman, Coronis. It is generally assumed that he was at first venerated as a local hero in Tricca in Thessaly, where his hero's grave may still be found, and that he subsequently became deified as a god. But there is also a minority opinion which totally dissociates the hero of Tricca from the later god of healing (Schouten 1967:8-11).

Mythographers differ widely about the origin of Asclepius. Probably the commonest version (that of Pindar, Pythian Ode 3.1-58) tells that Coronis was fatally wounded by an arrow from Artemis as punishment for her adultery, but that Apollo delivered the child from his dying mother on the funeral pyre and placed him in the care of Chiron, the Centaur, who taught him the art of healing. However, Pausanias (II.26.3-5) records that Coronis did not die, but delivered and abandoned her child near Epidaurus where he was suckled by the mountain goats. He was subsequently found by the local inhabitants, who immediately recognised his god-like features. In this way the healing shrine of Epidaurus, the first and best known of all Asclepieum shrines, originated, to be followed by similar Asclepiea at more than 200 sites, including Athens, Pergamum, Cos and even Rome. The latter shrine, on an island in the Tiber, originated in $293 \mathrm{BC}$ when, according to Livy (10.47.4) and Ovid (Metamorphoses XV.622-744), the elders of Rome terminated a terrible plague by bringing Asclepius to their city in the form of a snake from Epidaurus. Eventually, according to Pindar (Pythian Ode 3.1-58) and Euripides (Alcestis 1-7) Zeus, annoyed by Asclepius's success at curing illness and even raising people from the dead, struck him down with a lightning bolt - but later repented, raised him from the Underworld and elevated him to full divinity.

According to tradition, the family of Asclepius and their descendants devoted themselves to the art of healing. Hippocrates of Cos was said to have been an Asclepiad, although this term could also have indicated a medical guild. Asclepius's wife, Epione, had sacrifices offered to her at Epidaurus, and according to legend their two daughters followed in their father's footsteps: Hygieia was not a healer, but represented health, while Panacea became the personification of the all-healing powers of herbs and other medicines (Jayne 1925:248-9; Rakel 1985:2369). 
In the cult of Asclepius as performed at the healing shrines, serpents (to a lesser extent also dogs, goats and cocks) played an important role, and thus became incorporated in the staff and snake symbol. The Asclepiea were usually situated in healthy and picturesque surroundings with groves of trees and flowing fountains. The complex always included an abaton (open porch with roof) where patients underwent "incubation sleep" (sometimes under the influence of sleeping draughts) while the priests silently moved among the patients with their sacred serpents which often licked the individuals' lesions or injuries. Interpretation of patients' dreams formed an important part of the diagnostic and therapeutic procedures, which included massage, dietary and exercise therapy (Margotta 1967:52-57).

\subsection{Emblem of Hermes}

This consists of a thin rod or staff (caduceus) encircled by two snakes with their heads together at the top end of the staff. The single snake staff of Asclepius is sometimes also erroneously referred to as a caduceus (Hart 1972:1107-1108). The word is derived from a Greek root meaning "herald's wand", and is traditionally associated with the mythical Hermes (Latin, Mercurius), messenger of the gods and mediator between the realm of the dead and the kingdom of the living (Rakel 1985: 2369). The caduceus was indeed a magical wand, a gift from Apollo which protected Hermes and enabled him to guide departed souls along unknown pathways to the Underworld, and to awaken the sleeping. The latter aspect was sometimes associated with powers of resurrection of awakening the dead, and also of curing the severely ill (Schouten 1967:119; Van Rooyen 1982:731-5).

Hermes became the protector of travellers, merchants, shepherds and their flocks. As divine protector of merchants he was also called the "divine deceiver" in view of the negative connotation sometimes attached to merchants, and was thus also seen as protector of thieves (Rakel 1985:2369). In the third Homeric hymn, Apollo does indeed testify to all these attributes, and also refers to Hermes's prowess as initiator of dreams (Van Rooyen 1982:731-5), the night watchman, and the keeper of the gate. 


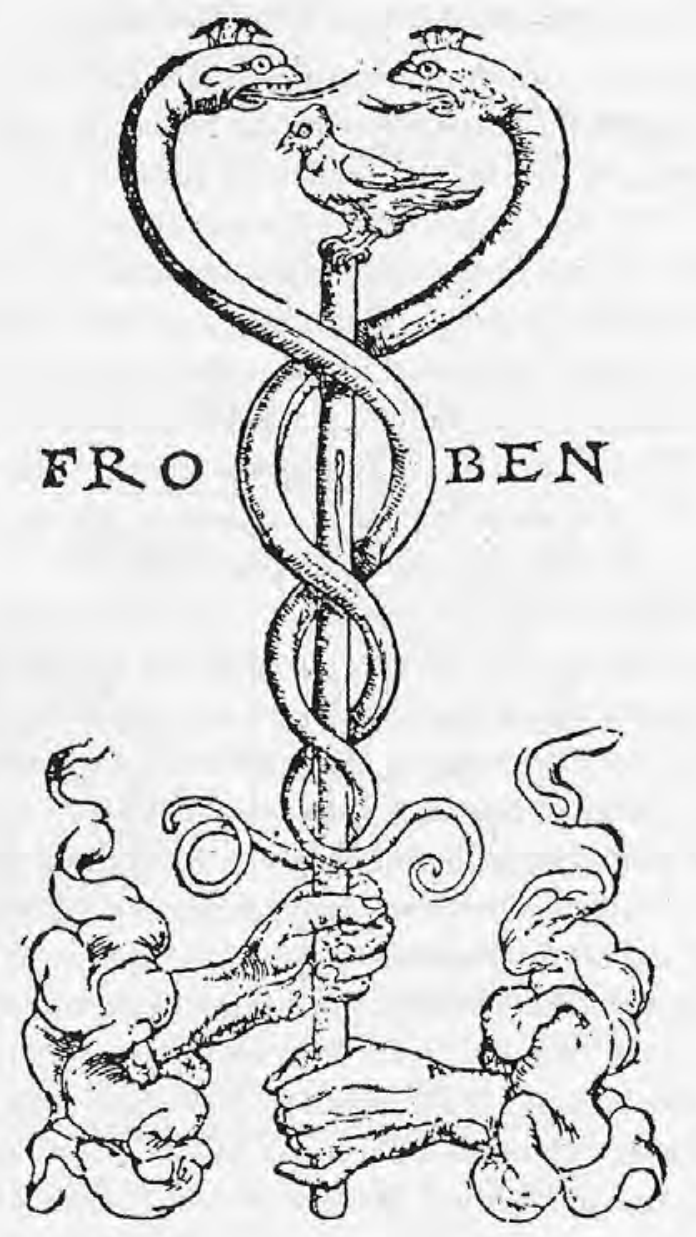

Figure 29: Symbol of Hermes (caduceus with double-snake). Printer's device of Johann Froben, $16^{\text {th }}$ century publisher of medical works.

This symbol, in different forms, does however have a history going back to long before the Greeks. Flint knives with exquisitely worked gold-foil and double-snake motifs on ivory handles dating back to 
$3100 \mathrm{BC}$ were found in Egypt. Similar designs of Mesopotamian origin date back to $2000 \mathrm{BC}$, including a famous double snake staff emblem on the libation cup of King Gudea (Bunn 1967:615-9). These were probably religious symbols relating to the gods of fertility and sexual powers, and were not really health related. Hart (1972:1110) suggests that in the mists of antiquity the caduceus originated as a phallic symbol and gradually developed into Hermes's herald's wand.

Not originally a health related emblem, the caduceus with the two snakes did, however, acquire this association during the late Middle Ages when it gradually became the emblem of alchemy and pharmacy. Schouten (1967:121-123) suggests that this association possibly originated in the $5^{\text {th }}$ century AD when Hermetica, a partly mystical document dealing with astrology, alchemy, magic and philosophy, became influential in suggesting that the planet Mercury (Hermes) was vitally important to Earth. The name mercurius philosophorum was subsequently given by the alchemists to quicksilver (mercury), considered as the first principle of all matter and metals in particular. Mercury/Hermes thus remained a dominant factor in alchemy and by the $16^{\text {th }}$ century the double-snake caduceus had become a medico-pharmaceutical emblem. John Caius, President of the Royal College of Physicians in 1556, presented the College with a caduceus ensign of honour for the president (Hart 1972:1107). Johann Froben, an eminent publisher of the $16^{\text {th }}$ century, was probably the first to use the caduceus emblem consistently in his medical publications (Fig. 29). In publishing and art the doublesnake caduceus now started appearing quite regularly as a medical emblem, in addition to the traditional Asclepius snake and staff. In the middle of the $19^{\text {th }}$ century J.S. Churchill, the famous London medical publishing firm, used the caduceus as printer's device, and in 1856 the wand of Hermes encircled by two snakes became the medical emblem of the U.S.A. Army Medical Service and subsequently also of the US Public Health Service. Hart (1972:1108-1109) described caduceus imprints of great antiquity on oculists' stamps found in London, perhaps dating back to Roman times, and suggests that it might be considered an original ophthalmic symbol. 


\section{DISCUSSION}

It is clear that Asclepius's snake and staff symbol was the emblem of health care in Graeco-Roman times. Asclepiea were in fact in vogue up to the $5^{\text {th }}$ century AD (Schouten 1967:16-17). The snake component of the emblem clearly relates at least partly to the sacred snakes which accompanied Asclepian priests on their rounds to the abata of Asclepiea. But at the time domestic snakes were also accepted by households as bringers of good fortune, and serpents were commonly associated with wisdom and longevity (Lurker 1989:37). The heavy wooden staff was probably a symbol of eternity as embodied in mother earth, rather than representing the walking stick of the dedicated physician always ready to travel anywhere for the good of his patients (Schouten 1967:118-120).

The origin of the caduceus is shrouded in mystery (Bunn 1967:615). It could well have originated as a phallic symbol, but during the early Egyptian era already a short and simple staff or rod was accepted as a regal sign of power. Decoration of the rod with two coiling snakes was already evident three millennia BC, and in Graeco-Roman mythology it became the magic wand of Hermes, messenger of the gods. It was not originally a symbol of healing, although indirect associations are detectable (Schouten 1967:118-120; Bunn 1967:615) — Hermes did, after all, accompany the dead to Hades, and might have had the power of resurrection. And many gods, including Hermes, were endowed with healing powers; Hermes was for instance associated with the birth myths of Dionysus (Schouten 1967:119). These legends are, however, too tenuous to support a basis of true medical significance. The caduceus's prominent association with the healing professions which arose during the late Middle Ages and the Renaissance was erroneous from a classical point of view but might have had an explicable origin in its association with alchemy (Schouten 1967:119-121). However, it did gain a foothold which has persisted to this day, and the magical wand of Hermes encircled by two snakes has been accepted in certain health professions and societies in lieu of the mythologically correct single snake emblem of Asclepius, in spite of the negative association of the former inter alia with dishonest trade practices and thievery.

As already mentioned, the U.S. Army Medical Department and the U.S. Public Health Service have (erroneously, in our opinion) adopted 
Snake and staff symbolism and healing

the double-snake caduceus as their emblem (Schouten 1967:132; Hart 1972:1109-1110), and so has the recently established S.A. Health Professions Council. However, the American Medical Association, the South African Medical Association and the World Health Organisation have all adopted the Asclepian emblem (Van Rooyen 1982:735). Three of South Africa's seven Health Science Faculties have a snake and staff emblem on their crests - two are Asclepian symbols and one the caduceus encircled by two snakes.

\section{REFERENCES}

\section{Allen N}

2000. The healing serpent in the Judaeo-Christian tradition. In: S. Kottek \& H. F. J. Horstmanshoff (eds.), From Athens to Jerusalem. Rotterdam: Erasmus, pp. 203-225.

BUNN J T

1967. Origin of the caduceus motif. Journal of the American Medical Association 202(7):615-619.

\section{FAN F S}

1992. The symbol of medicine in ancient China. S.A. Medical Journal 82:273274.

\section{HART G D}

1972. The earliest medical use of the caduceus. CMA Journal 107:1107-1110.

\section{HENDEL R S}

1995. Serpent. In: K. van der Toorn (ed.), Dictionary of deities and demons in the Bible (Leiden, New York, Köln: E.J. Brill), pp. 1404-1412.

JAYNE W A

1925. The healing gods of ancient civilizations. New Haven, Conn.: Yale Univ. Press.

LURKER M (ED.)

1989. Snakes. In: Dictionary of gods and goddesses, devils and demons (transl. by M. O’Connell). London: Routledge. 
Acta Theologica Supplementum 7

MARGOTTA R

1967. An illustrated history of medicine. London: Hamlyn.

RAKEL R E

1985. One snake or two? Journal of the American Medical Association 16:2369.

Rose H J

1996. Telesphorus. In: S. Hornblower \& A. Spawforth, Oxford Classical Dictionary. Oxford: Oxford University Press, p. 1480.

SCHOUTEN J

1967. The rod and the serpent of Asklepios. Amsterdam, London, New York: Elsevier.

VAN ROOYEN R J

1982. Die towerstaf van Hermes en die genesende staf van Asklepios. Geneeskunde 31:731-735.

WASSERMANN H P

1997. Geneeskunde in die Bybel. Pretoria: J.L. van Schaik. 